\title{
A bélbakterióta élettani jellemzői és a dysbacteriosis szerepe az elhízásban, inzulinrezisztenciában, diabetesben és metabolikus szindrómában
}

\author{
Halmos Tamás dr. ${ }^{1}$ - Suba Ilona dr. ${ }^{2}$ \\ ${ }^{1}$ Mazsihisz Szeretet Kórház, Metabolikus Ambulancia, Budapest \\ ${ }^{2}$ Bajcsy-Zsilinszky Kórház-Rendelőintézet, Tüdőgondozó, Budapest
}

\begin{abstract}
A belekben élő mikroflóra - bélbakterióta - évtizedek óta ismert, de egyre újabb funkcióit megismerve ismét a tudományos érdeklődés középpontjába került. A bélrendszerben 100000 billió baktérium él. A bélbakterióta a bélrendszer különböző szakaszaiban változó összetételben és mennyiségben helyezkedik el, életkortól, testsúlytól, földrajzi elterjedéstől, étrendtől függően. A normális bélflóra megvédi a szervezetet a káros mikroorganizmusok behatolásától, elősegíti az emészthetetlen rostok emészthetővé tételét, biztosítja a bélnyálkahártya integritását, befolyásolja a szervezet immunitását, inzulinérzékenységét, a testsúlyt, sőt az agy múködésével is kölcsönhatásban van. A bélbakterióta hatására a vastagbélben szénhidrátok fermentációjából rövid láncú zsírsavak - butirátok, acetátok, propionátok - keletkeznek, amelyek kedvezően hatnak a metabolikus folyamatokra. Új észlelés az agy-bél tengely létezése, a mikrobióta közvetlenül hat az agyi központokra, ahonnan információk érik a mikrobiótát. E kétirányú folyamatban részt vesz az immun- és neuroendokrin rendszer, az autonóm és a centrális idegrendszer is. A bélmikrobióta múködése függ a cirkadián ritmus változásától is. A gazdaszervezet és a bélflóra közötti egyensúly megbomlása dysbacteriosist okoz, Gram-negatív baktériumok által termelt endotoxinok (lipopoliszacharidok) jutnak a keringésbe (metabolikus endotoxaemia) a bélnyálkahártya permeabilitásának fokozódása útján, amelyek immunreakciót és gyulladást indukálnak. Ezek a folyamatok elhízást, inzulinrezisztenciát, diabetest, metabolikus szindrómát, gyulladásos bélbetegséget, autoimmunitást, daganatképződést okozhatnak. Biztató terápiás lehetőség e betegségek gyógyításában az egészséges bélflóra helyreállítása probiotikumok, prebiotikumok útján. Egészséges egyénből származó széklet transzplantációja az elhízott egyén minden kóros metabolikus paraméterét javította. Remélhető, hogy a mikrobióta alaposabb megismerése hatásos gyógymódok kifejlesztését fogja eredményezni. Orv. Hetil., 2016, 157(1), 13-22.
\end{abstract}

Kulcsszavak: mikrobióta, dysbiosis, metabolikus endotoxaemia, rövid láncú zsírsavak (SCFA-k), agy-bél tengely, fekális transzplantáció, bariátrikus sebészet

\section{Physiological patterns of intestinal microbiota. The role of dysbacteriosis in obesity, insulin resistance, diabetes and metabolic syndrome}

The intestinal microbiota is well-known for a long time, but due to newly recognized functions, clinician's attention has turned to it again in the last decade. About 100000 billion bacteria are present in the human intestines. The composition of bacteriota living in diverse parts of the intestinal tract is variable according to age, body weight, geological site, and diet as well. Normal bacteriota defend the organism against the penetration of harmful microorganisms, and has many other functions in the gut wall integrity, innate immunity, insulin sensitivity, metabolism, and it is in cross-talk with the brain functions as well. Brand new recognition, that intestinal microbiota has a direct effect on the brain, and the brain also influences the microbiota. This two-way gut-brain axis consists of microbiota, immune and neuroendocrine system, as well as autonomous and central nervous system. Emerging from fermentation of carbohydrates, short-chain fatty acids develop into the intestines, which produce butyrates, acetates and propionates, having favorable effects on different metabolic processes. Composition of the intestinal microbiota is affected by the circadian rhythm, such as in shift workers. Dysruption of circadian rhythm may influence intestinal microbiota. The imbalance between the microbiota and host organism leads to dysbacteriosis. From the membrane of Gramnegative bacteria lipopolysacharides penetrate into the blood stream, via impaired permeability of the intestinal mucosa. These processes induce metabolic endotoxaemia, inflammation, impaired glucose metabolism, insulin resistance, 
obesity, and contribute to the development of metabolic syndrome, type 2 diabetes, inflammarory bowel diseases, autoimmunity and carcinogenesis. Encouraging therapeutic possibility is to restore the normal microbiota either using pro- or prebiotics, fecal transplantation or bariatric surgery. Human investigations seem to prove that fecal transplant from lean healthy individuals into obese diabetic patients improved all the pathological parameters. Wide spread use of bariatric surgery altered gut microbiota and improved metabolic parameters apart from surgery itself. Pathomechanism is not yet cleared up. Clinicians hope, that deeper understanding of complex functions of intestinal microbiota will contribute to develop more effective therapeutic proceedings against diabetes, metabolic syndrome, and obesity.

Keywords: microbiota, dysbiosis, metabolic endotoxemia, short-chain fatty acids, gut-brain axis, fecal transplantation, bariatric surgery

Halmos, T., Suba, I. [Physiological patterns of intestinal microbiota. The role of dysbacteriosis in obesity, insulin resistance, diabetes and metabolic syndrome]. Orv. Hetil., 2016, 157(1), 13-22.

(Beérkezett: 2015. szeptember 9.; elfogadva: 2015. október 14.)

\section{Rövidítések}

$\mathrm{ADHD}=($ attention deficit hyperactivity disorder $)$ figyelemhiánnyal járó hiperaktivitás betegség; CD14 = cluster of differentiation 14, co-receptor; DNA = deoxiribonukleinsav; FFAR2 = zsírsavreceptor-2; FFAR3 = zsírsavreceptor-3; FMT = fecal microbiota transplantation; GBA = (gut-brain axis) agy-bél tengely; GLP-1 = (glucagon-like peptid-1) glükagonszerúen ható peptid-1; HDAC = histon deacetylase; HFD = high fat diet; IBD = (inflammatory bowel disease $)$ gyulladásos bélbetegség; innate $=$ veleszületett; IR = inzulinrezisztencia; IRS = insulin receptor substrate-1; LPS = lipopoliszacharidok; NASH = nem alkoholos steatohepatitis; OCD $=$ (obsessive compulsory disease) kényszerbetegség; RNA = (ribonucleinacid) ribonukleinsav; SCFA = (short-chain fatty acid) rövid láncú zsírsav; $\mathrm{T} 1 \mathrm{DM}=$ autoimmune type 1 diabetes; $\mathrm{T} 2 \mathrm{DM}=2$-es típusú diabetes; TLR4 = Toll-like receptor- 4

\section{Háttér}

A bélben élő mikroflóra több mint 100 éve ismert. A bélflóra, helyesebben bélmikrobióta olyan mikroorganizmus-speciesek komplex közössége, amely az állatok és az ember tápcsatornájában él. A bélmikrobióta fó kvalitatív és kvantitatív tulajdonságai az anaerob tenyésztési módszerek fejlődésének és újabban a biomolekuláris technológiának köszönhetően egyre pontosabban vizsgálhatók. A bélbaktériumok a colonban a széklet száraz anyagának 60\%-át teszik ki [1]. Az intestinalis bakterióta a bélrendszeren belül egész kis világot alkot. A bélflórát körülbelül 100000 billió baktérium alkotja, ami 10-szer több, mint a test sejtjeinek a száma, 300-1000 különböző specieshez tartoznak, súlyuk 1-2 kg, génjeik száma 3,3 millió, 150-szer több, mint a humán genom génjeinek száma [2,3]. A bélmikrobióta ekoszisztémát alkot a gazdaszervezeten belül [4], és legnagyobb rezervoárja azoknak a mikroorganizmusoknak, amelyek az emberrel kölcsönhatásban élnek [5]. A bélflóra és az ember közötti koegzisztencia nem pusztán „együtt létezés”, hanem kölcsönös kapcsolat. Ha két különböző specieshez tartozó organizmus él együtt és mindegyik aktivitása jótékonyan hat a másik félre, azt mutualismusnak nevezzük. A bélmikrobióma kifejezés a bélmikrobióta genomjait jelenti. (A genom valamely organizmus genetikai anyaga, DNA-ból vagy RNA-vírusokban RNA-ból áll [6].) A bélbakterióta metabolikus aktivitása egy szerv múködéséhez hasonlítható, „elfelejtett szervként” is említik [7]. A bélflóra a szervezet számára fontos környezeti tényező. A bélbaktériumok nagyfokú diverzitást mutatnak a földrajzi előfordulás, életkor, a táplálék összetétele, a testsúly, a gazdaszervezet immunválasza, a diurnalis ritmus szerint, de különbözhet egyes közösségekben (család, iskola, börtön stb.), egyénileg, sőt az egyénen belül is megváltozhat különböző betegségekben (IBD - inflammatory bowel disease, béldaganatok).

\section{A mikrobióta összetétele és megoszlása a béltraktus különbözö részeiben}

A mikrobióta nem homogénen oszlik meg a béltraktus különböző részeiben. A tápcsatorna egyes szakaszainak bélflórája jelentős különbségeket mutat mind a baktériumok fajtáit, mind mennyiségét tekintve. A baktériumok elhelyezkedése részben luminális, részben a nyálkahártyához adherens módon kötődnek. A csíraszám a legmagasabb a colonban [8]. A bélmikrobiótát 2 baktériumtörzs uralja, a Gram-negatív Bacteroides és a Gram-pozitív alacsony csíraszámú Firmicutes, más törzsek alulreprezentáltak, beleértve az Actinobacteriumokat, Fusobacteriumokat és a Verrucomicrobia törzseket [9]. E törzseken belül domináns baktériumcsoportok a Clostridium coccoides-Eubacterium rectalis csoport, a 
Clostridium leptum csoport (Firmicutes), BacteroidesPrevotella species (Bacteroidetes), Bifidobacterium és Atopobium genera (mindkettő Aktinobacterium) [10]. A Firmicutes a bacilusok osztályába tartoznak, emberi és egérmikrobiótában ritkák [9].

\section{Bélflóra és étrend}

Az egyes mikrobiótatörzsek és az étrend között szoros összefüggés van. A bél mikroflórája fóleg 3 enterotípusból áll: Prevotella, Bacteroides és Ruminococcus. A Prevotella elsősorban a szénhidrát- és egyszerü cukoralapú étrenddel kapcsolatos, amely a mezőgazdasági társadalmakra jellemző. A Bacteroides enterotípus dominanciája az állati eredetü fehérjét, aminosavakat és telített zsírokat tartalmazó nyugati étrenddel függ össze. Egy bizonyos enterotípus túlsúlya tehát utal a táplálék összetételére. Feltételezik, hogy a hosszú távú diétás beavatkozás az egyén egészségének javítását eredményezheti $[11,12]$. Ley nem tudott összefüggést igazolni a bélmikrobióta és a zsír-, illetve szénhidrátbevitel között. Tanulmánya trendszerú pozitív összefüggést mutatott magas zsírtartalmú étrend és Firmicutes között. Azoknál, akik a legtöbb szénhidrátot fogyasztották, mind a Bacteroides, mind a Firmicutes pozitívnak mutatkozott [13].

\section{A bélbakterióta földrajzi diverzitása}

A bélmikrobióta összetétele függ a populációk földrajzi elterjedésétől. Az olyan gének reprezentációja, mint például az aminosav-degradációban vagy vitamin-bioszintézisben részt vevő enzimeké, szignifikáns különbséget mutat az egyes populációk között (Amerikai Egyesült Államok, Malawi vagy amerikai-indián eredet) [14]. Jumpertz és mtsai önkénteseket vizsgálva arra az eredményre jutottak, hogy a Firmicutes relatív felszaporodása és a Bacteroides csökkenése megnövelheti az energia kinyerését és a zsír tárolását egy adott étrendből. Emberben a Firmicutes növekedése és a Bacteroides csökkenése fokozott energiahasznosulással és elhízással jár [15]. De Filippo és mtsai szintén jelentős különbséget fedeztek fel európai és afrikai, falun élő gyerekek mikrobióta-összetételében. Az afrikai falusi gyerekek tápláléka zsír- és fehérjehiányos, poliszacharidákban és növényi fehérjékben gazdag, az európai gyerekek tápláléka állati fehérjében és zsírokban gazdag volt. Az európai gyerekek bélflórájában a Firmicutes dominált, és csökkent a biodiverzitás. $\mathrm{Az}$ afrikai gyerekek székletében a Bacteroides dominált, és a biodiverzitás fokozott volt. A mikrobiótának ez a különbözősége tette lehetővé az emészthetetlen növényi eredetű poliszacharidák emészthetővé tételét afrikai gyerekekben. [16]. Ezek az eredmények a Bacteroides és a Firmicutes dominanciáját illetően ellentétesek Yatsunenko és Jumpertz eredményeivel.

\section{A mikrobióta életkor szerinti eltérései}

Normális foetusban a gastrointestinalis traktust korábban sterilnek tartották, de újabban kiderült, hogy mikrobakolonizáció már a foetusban is előfordulhat. Szülés idején és közvetlenül utána az anyától származó és a környezeti baktériumok kolonizálják a gyermek bélcsatornáját [17]. A székletmikrobióta az első 3 életév során a felnőttekével megegyezővé válik. A bélmikrobióta változatossága kifejezettebb felnőttekben, mint gyerekekben. Ugyanakkor az egyes egyének közötti különbség gyermekekben a kifejezettebb. A székletminták metagenomikus analízise felnőttekben a fermentációban, metanogenezisben, valamint az arginin, glutamát, aszpartát és lizin metabolizmusában részt vevő enzimek magas koncentrációját bizonyította. Az újszülött-mikrobiómában domináns enzimek a ciszteinmetabolizmusban és fermentációs utakban vesznek részt [14]. A mikrobióta összetétele idős emberekben nagyobb individuális különbségeket mutat, mint fiatalokban. Az idősebb egyének székletmikrobióta-összetétele korrelál az életmódbeli tényezőkkel, a közösség lokális viszonyaival, a hosszú távú kezelésekkel. A mikrobióta összetétele tartósan kórházban ápolt egyénekben kevésbé változatos, mint az otthoni közösségben élőké [18].

\section{Mikrobióta és a cirkadián ritmus}

Az intestinalis mikrobióta a cirkadián ritmus krónikus szétzilálása esetén megváltozhat. Bebizonyosodott, hogy a mikrobióta különböző kóros állapotok széles skálájában játszik szerepet. Arra azonban nincs bizonyíték, hogy a bélflórának saját, a gazda szervezetétől független intrinszik cirkadián szisztémája lenne, bár a cyanobacteriumokban sikerült cirkadiánritmus-szabályozó mechanizmust kimutatni. Nagy jelentőségú annak tisztázása, hogy a normális cirkadián rendszer szétzilálása időskorban, „jet-lag” utazókon, váltott múszakban dolgozókban, hétköznap és hétvégén eltérő alvási szokások esetén hogyan befolyásolja a különböző lokalizációjú mikrobiótát. Feltehetőleg számos megbetegedés, amely a cirkadián ritmus szétzilálása következtében lép fel, részben a bakteriális dysbiosis következménye [19].

\section{Az egészséges bélflóra funkciója (eubiosis)}

Az egészséges mikroflóra tagjai a felső légutakban, a belekben, a bőrön élnek és megvédik a szervezetet a patogén mikroorganizmusok behatolásától, ezenkívül más funkciókat is betöltenek. Az intestinalis bakterióta egészséges szervezetben elősegíti a múködéséhez szükséges élettani folyamatokat, az emészthetetlen rostokat emészthetóvé teszi, biztosítja a bélnyálkahártya integritását, szerepe van a veleszületett immunitásban, sőt az agy múködésével is kölcsönhatásban van (1.ábra). 


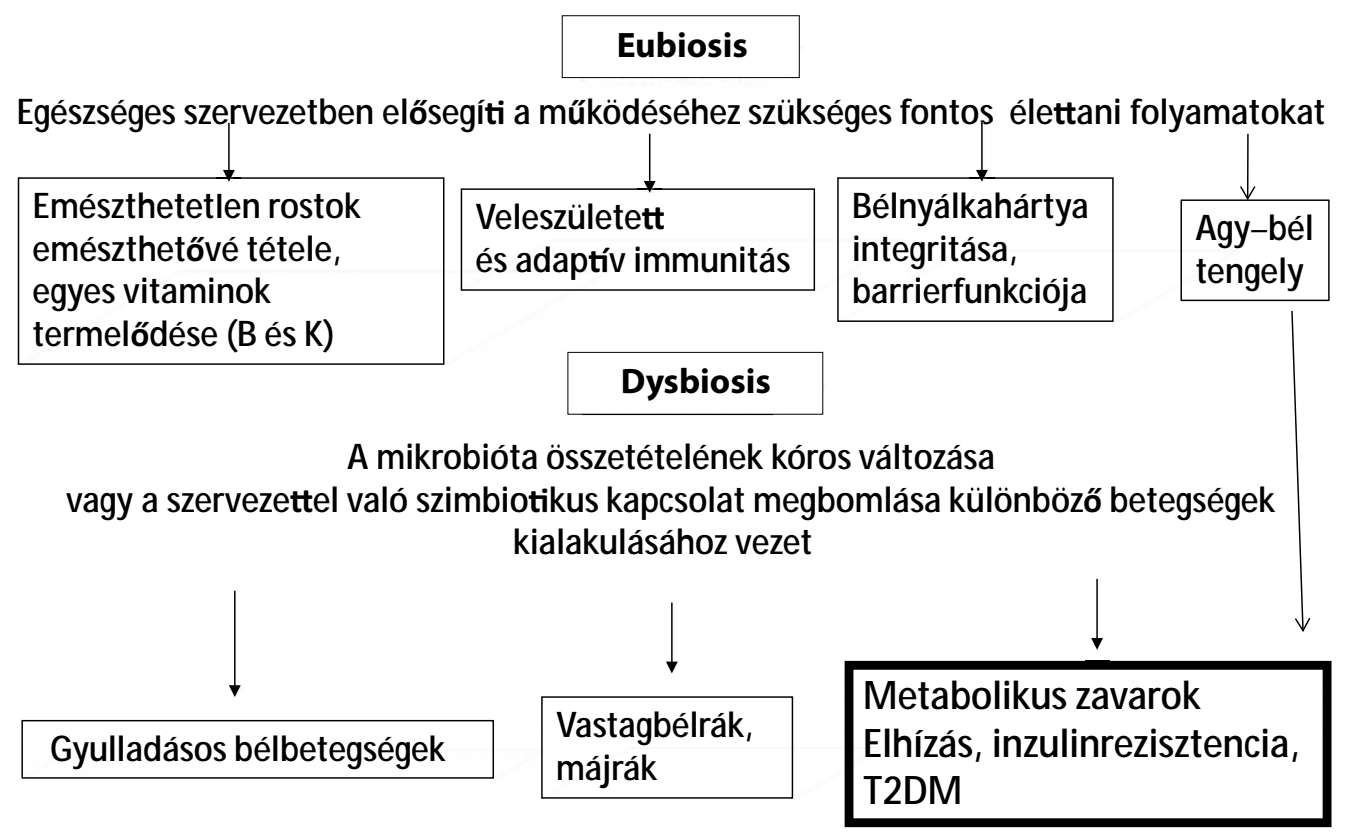

1. ábra

| A mikrobióta funkciója élettani és kóros körülmények között

\section{Rövid szénláncú zsirsavak}

A bél-mikroorganizmusok jótékonyan hatnak a gazdaszervezetre azáltal, hogy az emészthetetlen szénhidrátok fermentációja útján energiát termelnek, és elősegítik rövid láncú zsírsavak (short-chain fatty acids - SCFAs) keletkezését és felszívódását. A rövid láncú zsírsavak alifás lánca 6-nál kevesebb szénatomot tartalmaz [20]. SCFA-k akkor keletkeznek, ha a diétás rostok, legnagyobb részt szénhidrátok és fehérjék, fermentálódnak a colonban $[21,22]$. Ez a folyamat lehetővé teszi a gazdaszervezet számára, hogy „megmentse” azt az energiát, ami a gastrointestinalis traktus felsőbb részeiben nem emészthető szénhidrátokból és fehérjékből szabadul fel. Az SCFA-k minor táplálékforrások, különösen nyugati diétán élő emberekben. A legfontosabb ilyen zsírsavak a colon epitheliuma által metabolizálódó butirátok, a májban metabolizálódó propionátok és az izomszövetben metabolizálódó acetátok. Az intestinalis baktériumok szerepet játszanak a B-vitamin és K-vitamin szintézisében, valamint az epesavak, szterolok metabolizálásában [2]. Az SCFA-k kapcsolatosak a bélflóra összetételével obesitasban és egyéb metabolikus állapotokban. Újabban identifikálták a speciálisan SCFA aktiválta receptorokat. Ezek a receptorok, a szabad zsírsavreceptor-2 és -3 (FFAR2 és FFAR3), nemcsak a bélepitheliumban expresszálódnak, ahol az SCFA-k keletkeznek, hanem számos más metabolikusan fontos helyen, így a zsírszövetben és a pancreasszigetsejtekben is [22]. Az SCFA-k javítják a metabolikus funkciókat T2DM-ben (2-es típusú diabetes). Az SCFA-k HDAC (histon deacetylase) inhibitorként direkten hatnak a pancreas- $\beta$-sejtek múködésére, elősegítik a $\beta$-sejtek proliferációját és differenciálódását, indirekt módon fokozzák a GLP-1-szekréciót az enteroendokrin L-sejtekben, ami inzulinfelszabaduláshoz vezet. Az SCFA-k csökkentik a zsírszövetben a proinflammatorikus citokinek termelődését és gyengítik a leukocytaaktivációt. Ezek az antiinflammatorikus hatások csökkentik az inzulinrezisztenciát, javítják a glükózfelvételt és csökkentik a vércukorszintet [23]. Egérben kimutatták, hogy a butirátok, acetátok és propionátok védelmet nyújtanak étrend okozta elhízás és inzulinrezisztencia kialakulása ellen. A butirát és propionát serkentette a bélhormonokat és csökkentette a táplálékbevitelt. Ezek a hatások az FFAR3-tól függetlenek voltak, ami arra utal, hogy egyéb mediátorok szükségesek e jótékony hatások eléréséhez [24].

\section{A bélbaktériumok szerepe az immunitás szabályozásában}

A bélmikrobióta az immunhomeosztázis szabályozása útján is elősegíti a gazdaszervezet egészséges működését. A bélflóra megváltozása immundiszregulációt és autoimmun zavarokat okozhat. A bélmikrobióta regulálja az innate (veleszületett) és adaptív (szerzett) immunitást, amelyek zavara nemcsak intestinalis, hanem szisztémás autoimmun betegségeket okoz. Ennek a bonyolult folyamatnak az ismertetése meghaladná e dolgozat kereteit [25]. A T-sejteknek centrális szerepe van az adaptív immunitás és az immuntolerancia szabályozásában. A Tsejt-differenciálódást az érés és az effektor funkció tekintetében számos tényező szabályozza. Ilyenek az antigének, kostimulációs szignálok és citokinek. A táplálékok, a mikronutriensek, nukleáris hormonok, SCFA-k és más mikrobiális termékek is alapvető hatással vannak a T-sejtekre, direkt és indirekt módon szabályozzák azok differenciálódását [26]. 


\section{Agy-bél tengely}

Állatkísérletek és humán megfigyelések igazolják, hogy a bélbaktériumok jelzéseket küldenek az agyba és hatással vannak a viselkedésre. Az agy-bél tengely (gut-brain axis - GBA) kétirányú kapcsolat a centrális és intestinalis idegrendszer között, amely összeköttetést létesít az agy emocionális és kognitív központja, valamint az intestinalis funkció között, s a mikrobióta fontos szerepet játszik e kölcsönhatásban. A GBA és a mikrobióta közötti kétirányú interakciók jelátvitel útján jutnak az agyba, és vissza a bélhez neuralis, endokrin és humorális kapcsolatokon keresztül [27]. A kétirányú kapcsolat az agy és a bélmikrobióta között elengedhetetlen a homeosztázis fenntartásához. A bél-agy tengelybe beletartozik a központi idegrendszer, a neuroendokrin és a neuroimmun szisztéma, az autonóm, a centrális idegrendszer és az intestinalis mikrobióta. E kölcsönös kapcsolatban mind az agy képes befolyásolni a bélmikrobiótát (például stressz hatására megváltozik a mikrobióta összetétele), mind a mikrobióta hatással van az agyra, befolyásolja a magatartást, az immunválaszt és a vegetatív idegrendszer múködését. Ennek a kölcsönhatásnak a pontosabb tisztázása a jövőben biztató eredményeket hozhat a terápiában. A probiotikumok számos metabolikus, magatartásbeli és kognitív múködést képesek modulálni [28, 29].

\section{A dysbiosis}

A mikrobióta és a gazdaszervezet közötti koegzisztencia bizonyos körülmények hatására patológiássá válik. A dysbiosis vagy dysbacteriosis az emberrel szimbiózisban élő baktériumok abnormális állapota a bélben, a hüvelyben vagy a bőrön. A dysbiosis oka általában a patogén baktériumok, gombák vagy paraziták túlzott elszaporodása. A dysbiosis különböző betegségek kialakulásához vezet, így gyulladásos bélbetegségek (IBD), daganatok, metabolikus kórképek, diabetes, inzulinrezisztencia, elhízás alakulhat ki.

\section{Transzlokáció}

A hasznos baktériumok is ártalmasakká válhatnak a gazdaszervezetre, ha kikerülnek a béltraktusból. Transzlokáció akkor következik be, ha a baktériumok a mucosán, a bél és a test közötti határon keresztül elhagyják a bél lumenét és bejutnak a szervezetbe, mint ahogy ez bizonyos betegségekben előfordulhat (például cirrhosis). A transzlokációt okozhatja, ha túl sok baktérium szaporodik fel a vékonybélben, ha csökken a gazdaszervezet immunitása vagy megnő a bélfal permeabilitása [30].

\section{Antimikrobiális proteinek}

Az antimikrobiális fehérjék az intestinalis mikrobióta összetételének fontos szabályozói. Az antimikrobiális proteinek gyakran litikus enzimek, míg más antimikrobi- ális peptidek a mikrobák sejtmembránszerkezetének vagy múködésének destrukciója által hatnak. Egyes antimikrobiális peptidek konstitutív módon termelődnek, másokat gyulladás vagy fertőzés indukálja. Hatásukra a bélmikrobióta összetételében változások lépnek fel, amelyek endotoxinok beáramlását segítik elő a keringésbe. Ezek alacsony fokozatú gyulladást és inzulinrezisztenciát okoznak. Telített zsírok az étrendben fokozzák a patogén hatást, károsítva az epithelsejtek védőgát funkcióját. Rostokban gazdag étrend serkenti a rövid láncú zsírsavak termelését, az energia hasznosulását és védi a szervezetet a gyulladás és inzulinrezisztencia ellen [31].

\section{Lipopoliszacharidok}

A lipopoliszacharidok (LPS) endotoxinok, a Gram-negatív baktériumok külső membránjában található mérgező anyagok, különösen gyakoriak az élősködő életmódot folytató, patogén baktériumfajokban. A szervezet számára káros hatású bélbaktériumok indítják meg a lipopoliszacharidok okozta gyulladást. A Toll-like receptor-4 (TLR4) az LPS-receptor, amelynek igen fontos szerepe van az innate immunitásban. Az TLR4 stimulációja gyulladásos folyamatokat aktivál és citokinexpressziót indukál a különböző sejttípusokban. A LPS-ek egy CD-14 (cluster of differentiation 14) koreceptor által, a TLR4hez kötődve indítják meg az inflammatiós folyamatot, amelynek fontos szerepe van az obesitással kapcsolatos inzulinrezisztenciában. Adatok szólnak amellett, hogy a TLR4 a molekuláris kapcsolat a táplálkozás, lipidek és az inflammatio között, és hogy az innate immunrendszer részt vesz az energia-egyensúly és az inzulinérzékenység szabályozásában, alkalmazkodva az étrend változásaihoz. A TLR-receptor „kiütése” kivédi a magas zsírtartalmú diéta (high fat diet - HFD) okozta inzulinrezisztenciát (IR) [32]. A bélbakterióta összetételének változása, a Bifidobacteriumok és az Eubacteriumok redukciója, a keringő LPS-ek szintjének növekedése metabolikus endotoxaemiát okozott egérben [33].

\section{Metabolikus endotoxaemia}

Cani, Amar és mtsai kimutatták, hogy a HFD megváltoztatta a bélmikrobiótát, fokozódott a bélfal permeabilitása, megnövekedtek a plazma-LPS-szintek, és ezt metabolikus endotoxaemiaként definiálták [34]. Az endotoxaemia tehát a bélnyálkahártya kóros átjárhatóságának következménye, toxinok kerülnek a keringésbe és a gazda immunválasza által gyulladás alakul ki. Az LPSinfúzió a HFD-hez hasonló metabolikus eltéréseket eredményezett. A CD-14 koreceptor az LPS-t az LPSkötő protein jelenlétében megköti. Ha az LPS-receptorokat kiütik, az egerek rezisztensnek mutatkoztak mind a HFD-, mind az LPS-infúziók adására, azt jelezve, hogy a CD-14 módosítja az inzulinérzékenységet [35]. A CD14 koreceptor a TLR-4 „minta (pattern) -felismerő receptor" és az MD-2 (lymphocyte antigen 96) által al- 
kotott heterodimer komplexszel együtt a Gram-negatív baktériumból származó LPS felismerését végzi. Az endotoxaemia kulcsszerepet játszik obesitashoz társuló gyulladás kifejlődésében. A táplálék befolyásolja a plazmaendotoxin szintjét [33].

\section{Mikrobióta és inflammatio}

A bélbaktériumok részt vesznek a HFD okozta metabolikus endotoxaemia kifejlődésében, a zsírszövet gyulladásában és a metabolikus zavarokban [34]. Étrend okozta és genetikailag elhízott egerekben (ob/ob vagy db/db) a Toll-like receptorok 1-9 expressziójának szignifikáns fokozódását lehetett kimutatni adipocytákban és praeadipocytákban, fokozott citokintermeléssel együtt [36]. A TLR-4 mind az LPS, mind a HFD által aktiválható, ami beindítja a gyulladásos folyamatokat a zsírsejtekben és makrofágokban. A metabolikus endotoxaemia, az LPS-ek szérumbeli felszaporodása gyulladásos tényező, amely inzulinrezisztenciát, testsúlynövekedést és diabetest okozott HFD-vel táplált állatmodellben [10, 37, $38]$.

\section{Mikrobióta és inzulinrezisztencia}

A bélmikrobiótát lehetséges hozzájáruló (additív) tényezőként azonosították metabolikus betegségekben. Kimutatták, hogy elhízott egyének baktériumflórája eltérő a soványakéhoz képest, a Firmicutes és Actinobacteria megszaporodott, míg a Bacteroides csökkent. Ez a változás az intestinalis permeabilitás fokozódásával jár, megnövelve az LPS abszorpcióját, amely a keringésbe jutva aktiválja a TLR-4 és -3 receptort, ezáltal gyulladásos folyamatokat indukál. A Toll-like receptor 4-nek fontos szerepe van az inflammatióban és az immunitásban, expressziója a szervezet legtöbb szövetében kimutatható, ezen belül az inzulinérzékenyekben is. Mivel LPS-ek és FFA-k aktiválják, amelyek az inzulinrezisztencia kiváltói, a TLR4-nek kulcsszerepe lehet az inflammatorikus és metabolikus szignálok közötti kölcsönhatásban. Az inflammatio rontja az inzulin-jelátvitelt, az inzulinreceptor és az IRS (insulin receptor substrate-1)/Akt foszforilációját. A bélmikrobióta változásai különböző jelátviteli aktivációt és fenotípus-változásokat eredményeznek, lehetőségeket teremtenek az elhízás és a T2DM kezelésére [39].

\section{Dysbiosissal kapcsolatos betegségek}

\section{Mikrobióta és obesitas}

Az elhízás olyan metabolikus betegség, amelyet inzulinrezisztencia és alacsony fokozatú gyulladás jellemez. Ehhez a genetikus hajlam, környezeti tényezők, a táplálék minősége és mennyisége a bélmikrobióta közvetítésével, közösen járulnak hozzá [40]. Rágcsálókon és emberben végzett tanulmányok igazolták, hogy a bélmikrobióta összetétele változik sovány, illetve túlsúlyos egyénekben. Feltételezik, hogy az „obesus mikrobióma” hozzájárulhat a diétából származó energia fokozott hasznosításához, és ez végül is elhízáshoz vezethet [41]. Jumpertz és $m t s a i$ „pyrosequencing bacterial rRNA gene" technikával a microbióta szerepét vizsgálták a táplálék felszívódásának szabályozásában 12 sovány és 9 elhízott egyén székletében. Az elfogyasztott és a székletben lévő kalóriákat kalorimetriásan mérték és összehasonlították. Azt találták, hogy az előzőektől eltérő táplálék változásokat indukált a mikrobiótában, ami egyenesen korrelált a széklet kalóriaveszteségével és a kinyert energia körülbelül 150 kcal-ás növekedésével. Ez arra utal, hogy a mikrobiótának lényeges szerepe van a táplálék hasznosulásában $[15,42]$.

Patrice és mtsai azt találták, hogy a plazma LPS-szintje jóllakott, illetve éhomi állapotban növekedett vagy csökkent a táplálék összetétele szerint, de egy 4 hetes HFD 2-3-szorosára növelte a plazma-LPS koncentrációját. Ez az a küszöbérték, amely felett metabolikus endotoxaemiáról beszélünk. A HFD megnövelte az LPS-t tartalmazó mikrobióta részarányát a bélben. Ha egérben a metabolikus endotoxaemiát 4 héten keresztül folyamatos LPSinfúzióval fenntartották, az éhomi hyperglykaemia, hyperinsulinaemia, testsúly, a máj- és zsírszövet hasonló nagyságrendben növekedett, mint HFD hatására. Ugyancsak megszaporodtak a zsírszöveti F4/80 pozitív sejtek (inflammatorikus makrofágok), a gyulladásos markerek és megnőtt a máj trigliceridtartalma. CD 14-mutáns egerek ellenállóknak bizonyultak mind az LPS-, mind a HFD-infúziók hatásának. Ez arra utal, hogy a metabolikus endotoxaemia az, ami gyulladást, ezáltal testsúlynövekedést és diabetest okoz. Következésképpen az LPS/CD14 rendszer befolyásolja az inzulin iránti szenzitivitást, valamint a diabetes és elhízás kialakulását. A plazma-LPS koncentrációjának csökkentése a metabolikus betegségek kezelésének hatásos stratégiája lehet $[34,43]$. Állatokon nyert tapasztalatok arra utaltak, hogy a HFD az obesitastól függetlenül is modulálja a mikrobióta összetételét, a Firmicutes megszaporodik, és a Bacteroides arányosan csökken [44]. Az elhízásban oki szerepet játszó speciális mikrobák azonosítása azért fontos, mert ez lehetőséget nyújthat az obesitas célzott kezelésére [42].

\section{A mikrobióta szerepe az MS kialakulásában}

A bélmikrobiótának szerepe van a metabolikus szindróma kialakulásában. Ezt mind humán, mind állatkísérletes vizsgálatok eredményei igazolják. Ez a komplex „szuperorganizmus" fontos szabályozója a gazdaszervezet anyagcsere-egyensúlyának, befolyásolva az energia felszívódását, a belek motilitását, az étvágyat, a glükóz- és lipidmetabolizmust, valamint a máj zsírtárolását. A bélmikrobióta és a gazdaszervezet immunrendszere közötti finom egyensúly megromlása, a „metabolikus endotoxae- 
mia” szisztémás gyulladáshoz és IR-hez vezet. Ennek patomechanizmusát fentebb részletesen ismertettük és a 2. ábrában foglaljuk össze.

A bélmikrobióta szerepet játszik a metabolikus szindróma komponense, a nem alkoholos steatohepatitis (NASH) kialakulásában. Az idevezető patomechanizmus a bakteriális etanoltermelés, a cholin és epesavak anyagcseréjének megváltozása, a hepatocyták lipogenezisének stimulációja és a megnövekedett intestinalis permeabilitás. A mikrobiális antigének és a cytosolicus gyulladáskeltők kölcsönhatása okozza a gyulladásos kaszkád és a májfibrosis kialakulását. Az etanol szintjének szignifikáns növekedését a keringésben az etanoltermelő baktériumok, mint Enterobacteriaceae és Escherichia coli, intestinalis túlszaporodása okozza, amelyeket NASH-betegekben kimutattak [45]. Újabban kolinhiányos étrend kísérletes adása a Gammaproteobacteria és Erysipelotrichi intestinalis koncentrációjának változásával járt, amely közvetlenül összefüggött a máj zsírtartalmának mennyiségével [46]. Megfelelően múködő innate immunrendszer, alacsony zsír- és magas rosttartalmú diéta együtt fontos tényező a dysbiosis, valamint a metabolikus szindróma és a kapcsolódó cardiovascularis betegségek megelőzésében [31].

\section{Mikrobióta és diabetes}

T2DM-ben a hyperglykaemia, IR, gyulladás és oxidatív stressz járul hozzá a béta-sejt-múködés fokozódó romlásához és a béta-sejt-tömeg csökkenéséhez. SCAF-ek javítják a T2DM jellegzetes eltéréseit. A legfontosabb kedvező aktivitásukat a szérumglükózszint csökkenése, az IR, a gyulladás redukciója és a protektív hatású GLP-1- szint szekréciójának növekedése jellemezte [41]. Az intestinalis mikrobióta fontos szerepet játszik a T1DM kialakulásában és inzulinrezisztens T2DM kifejlődésében. Kóros bélmikrobióta szorosan kötődik e kórképekhez mind rágcsálókban, mind emberi modellben [47].

\section{Dysbiosis és mentális zavarok}

A bél-agy tengely biztosítja a szervezet homeosztázisát, de rendellenességek esetén számos metabolikus és mentális betegség kiváltásában lehet kóroki szerepe [48]. A bélmikrobióta megváltozása funkcionális gastrointestinalis zavarokat, szorongást, depressziót és kényszeres viselkedést okozhat, autizmusban is szerepe van. Probiotikum adása kedvező hatással volt a kényszerbetegségek (obsessive compulsory disease - OCD) tüneteire és a figyelemhiánnyal járó hiperaktivitásra (attention deficit hyperactivity disorder - ADHD) $[30,49]$. E folyamatok jobb megértése új kezelési lehetőségeket tárhat fel.

\section{A higiénés hipotézis}

A medicinában a higiénés hipotézis egy olyan elmélet, amely szerint, ha túlzott higiénés rendszabályok a korai gyermekkorban megakadályozzák a különböző fertőző ágensekkel (szimbiotikus mikroorganizmusok, bélflóra) való találkozást, megnöveli a fogékonyságot allergiás, autoimmun betegségekre, l-es típusú diabetesre, gátolva az immunrendszer természetes fejlődését. Ezt az elméletet „biome depletion theory” (biomahiányos) vagy "lost friends theory" (elvesztett barátok) elméletnek is szokás nevezni [40].

\section{Magas zsírtartalmú étrend}
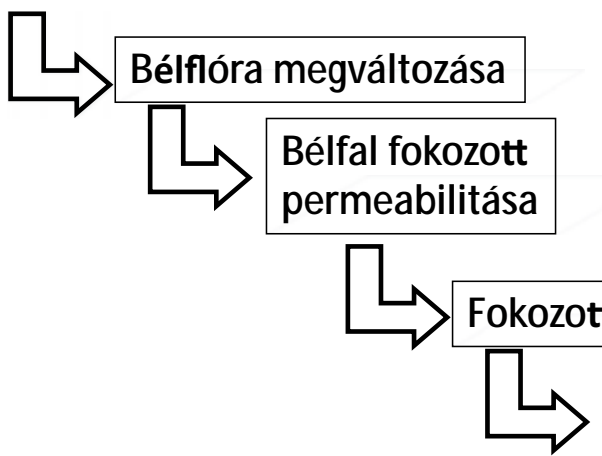

\section{Metabolikus endotoxaemia}

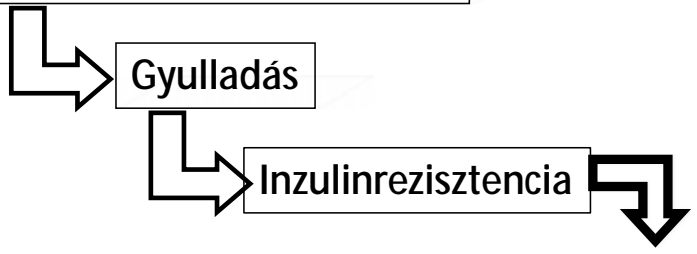

Metabolikus betegségek 


\section{A bélbakterióta manipulálásának lehetőségei}

Megismerve az intestinalis mikrobióta szerepét a fent részletezett betegségek patogenezisében, lehetőség nyílik alternatív terápiák kifejlesztésére [42].

\section{Probiotikus baktériumok, prebiotikumok, antibiotikumok}

A probiotikumok olyan táplálékkiegészítők, amelyek az emberi szervezet szempontjából jótékony baktériumokat tartalmaznak. A probiotikus baktériumkultúrák a természetes bélflóra helyreállítását segítik, pozitívan befolyásolják az immunrendszert. Probiotikumok fenntarthatják a normális intestinalis permeabilitást. A leggyakrabban előforduló probiotikus baktériumok a Lactobacillus és a Bifidobacterium törzsekbe tartoznak [50]. Probiotikumok adása indokolt szisztémás immunmoduláció, metabolikus szindróma, májkárosodás, gyulladásos bélbetegség, colorectalis rák és besugárzás okozta enteritis esetén [51]. A prebiotikum olyan természetes élelmiszer-összetevő, amelyre a gyomor-bél rendszer felső szakaszában található emésztőenzimek nem hatnak, és változatlan formában jutnak el a vastagbélig, ahol serkentik a probiotikumok szaporodását, javítják a probiotikus baktériumok hatásait vagy megakadályozzák a kártevő kórokozók növekedését. Az antibiotikumok gátolják a káros baktériumok növekedését és hatásait. Antibiotikus kezelés szignifikánsan csökkenti a plazma LPS-szintjét, a bél permeabilitását és a zsírszövet gyulladását, az oxidatív stresszt, a makrofágbeszúrődést és a metabolikus eltéréseket.

\section{Egyéb gyógyszeres terápiás lehetőségek}

TLR4-re ható gyógyszerek a veleszületett immunrendszerre hatnak. Az Eritoran kísérleti gyógyszer, súlyos szepszisre, fertőzésre létrejött excesszív gyulladásos válasz kezelésére, Japánban fejlesztették ki, szintetikus lipid, amely gátolja a LPS-ek kötődését a sejtfelszíni MD2-TLR4 receptorokhoz. Az NFkB inhibitorok a proinflammátoros citokinexpressziót csökkentik.

\section{Széklettranszplantáció}

A székletmikrobióta-transzplantációt (fecal microbiota transplantation - FMT) már több mint 50 éve alkalmazzák [52], igen hatékony a Clostridium difficile-fertőzések eradikációjában $[53,54]$. Újabban ismét az érdeklődés előterébe került az FMT mint terápiás lehetőség obesitasban és metabolikus szindrómában. HFD-vel táplált obes egerek egy részének ivóvízben E. coli Nissle-1917 baktériumokat adtak, másik részük csak vizet vagy kontrollbaktériumokat kapott. A modifikált baktériumokat kapó egerekben szignifikánsan csökkent a táplálékfelvétel, az elhízás mértéke, az inzulinrezisztencia és a hepatosteatosis a kontrollegerekhez képest. A modifikált baktériumok inkorporációja a bélmikrobiótába eredményesen gátolta a metabolikus elváltozások kialakulását [55]. Sovány férfi donorból metabolikus szindrómás férfibe történő fekális transzplantáció (FMT) szignifikánsan javította az inzulinérzékenységet és megnövelte a mikrobiális diverzitást, ezen belül a butiráttermelő törzsek szaporodását. A butirát jótékony anyagcserehatásai a mitochondrialis aktivitás fokozódása, a metabolikus endotoxaemia megelőzése és az intestinalis glükoneogenezis aktivációja különböző gének expressziója és hormonális szabályozás útján. Az FMT alkalmazásának eddig is ígéretesek az eredményei, és remélhetőleg a jövőben tovább bővülnek a mikrobiótán alapuló terápiás lehetôségek [41].

\section{Bariátrikus sebészet}

A bariátrikus sebészet jelenleg a kóros elhízás hosszú távú kezelésének leghatékonyabb módszere. Obes kontrollokhoz képest csökken a cardiovascularis kockázat és a rákincidencia. A bariátrikus sebészet által indukált mikrobiális és metabolikus változások hozzájárulhatnak a sebészeti testsúlycsökkentéshez, a kedvező anyagcserehatásokhoz és a csökkent mortalitáshoz [56]. Az elhízás és a T2DM gyógyítása bariátrikus sebészeti beavatkozással elérhető cél lett. Populáris bariátrikus eljárások, mint a Roux-en-Y gastricus bypass és „ingujj” gastrectomia nagy gyakorisággal a diabetes remisszióját vagy a glükózanyagcsere jelentős javulását eredményezi. Ennek mechanizmusa még nehezen érthető, sokféle anatómiai és fiziológiai változás, kalóriarestrikció, javuló $\beta$-sejtfunkció - a GLP-1 fokozott termelése következtében -, mindezek a bélfiziológia, bélbakterióta és az epesav-metabolizmus megváltozásának következményei [57].

\section{Következtetések}

A bélbakterióta mintegy „szuperszervként” a szervezet csaknem minden fontos múködését befolyásolja. Szerepe a gyulladásos bélbetegségekben régóta ismert és nyilvánvaló. A bélflóra utóbbi évtizedben intenzív kutatások tárgya, fény derült szerepére az anyagcserében, az innate és adaptív immunitásban, sőt meglepetésként az agyi müködésben és a viselkedés befolyásolásában is. Rendkívüli változékonysága által elősegíti a szervezetnek a környezethez való alkalmazkodását. Ebből következik, hogy dysbiosis esetén mindezen funkciók zavara miatt olyan betegségek alakulnak ki, amelyek kezelésében a mikrobióta helyreállításának lényeges adjuváns vagy önálló szerepe lehet. Fontos ezért megelőzésként egészséges életmóddal a bélbakterióta integritásának megőrzése, illetve szükség esetén annak helyreállítása a már rendelkezésre álló manipulatív lehetőségek által. Természetesen fontosak a további kutatások a bakterióta múködésének mélyebb megértése és új terápiás lehetőségek keresése céljából. 
Anyagi támogatás: A közlemény megírása anyagi támogatásban nem részesült.

Szerzői munkamegosztás: A munkát a szerzők 50-50\%ban végezték. A cikk végleges változatát mindkét szerző elolvasta és jóváhagyta.

\section{Érdekeltségek: A szerzőknek nincsenek érdekeltségeik.}

\section{Irodalom}

[1] Stephen, A. M., Cummings, J. H.: The microbial contribution to human faecal mass. J. Med. Microbiol., 1980, 13(1), 45-56.

[2] Ottman, N., Smidt, H., de Vos, W. M., et al.: The function of our microbiota: who is out there and what do they do? Front. Cell. Infect. Microbiol., 2012, 2, 104

[3] Qin, J., Li, R., Raes, J., et al.: A human gut microbial gene catalogue established by metagenomic sequencing. Nature, 2010, 464(7285), 59-65.

[4] Savage, D. C.: Microbial ecology of the gastrointestinal tract. Ann. Rev. Microbiol., 1977, 31, 107-133.

[5] Sears, C. L.: A dynamic partnership: Celebrating our gut flora. Anaerobe, 2005, 11(5), 247-251.

[6] Ridley, M.: Genome. The autobiography of a species in 23 chapters. Harper Perennial, New York, 2006.

[7] O'Hara, A. M., Shanahan, F.: The gut flora as a forgotten organ. EMBO Rep., 2006, 7(7), 688-693.

[8] Baffy, Gy.: Human microbiota and gastrointestinal cancers. [A humán mikrobióta és az emésztószervi rákbetegségek.] Magyar Belorvosi Archívum, 2015, 68(1), 46-55. [Hungarian]

[9] Eckburg, P. B., Bik, E. M., Bernstein, C. N., et al.: Diversity of the human intestinal microbial flora. Science, 2005, 308(5728), 1635-1638.

[10] Abdallah Ismail, N., Ragab, S. H., Abd El Baky, A., et al.: Frequency of Firmicutes and Bacteroidetes in gut microbiota in obese and normal weight Egyptian children and adults. Arch. Med. Sci., 2011, 7(3), 501-507.

[11] Wu, G. D., Chen, J., Hoffmann, C., et al.: Linking long-term dietary patterns with gut microbial enterotypes. Science, 2011, 334(6052), 105-108.

[12] David, L. A., Maurice, C. F., Carmody, R. N., et al.: Diet rapidly and reproducibly alters the human gut microbiome. Nature, 2014, 505(7484), 559-563.

[13] Ley, R. E.: Obesity and the human microbiome. Curr. Opin. Gastroenterol., 2010, 26(1), 5-11.

[14] Yatsunenko, T., Rey, F. E., Manary, M. J., et al.: Human gut microbiome viewed across age and geography. Nature, 2012, 486(7402), 222-227.

[15] Jumpertz, R., Le, D. S., Turnbaugh, P. J., et al.: Energy-balance studies reveal associations between gut microbes, caloric load, and nutrient absorption in humans. Am. J. Clin. Nutr., 2011, 94(1), 58-65.

[16] De Filippo, C., Cavalieri, D., Di Paola, M., et al.: Impact of diet in shaping gut microbiota revealed by a comparative study in children from Europe and rural Africa. Proc. Natl. Acad. Sci. U.S.A., 2010, 107(33), 14691-14696.

[17] Bettelheim, K. A., Breadon, A., Faiers, M. C., et al.: The origin of $\mathrm{O}$ serotypes of Escherichia coli in babies after normal delivery. J. Hyg. (Lond.), 1974, 72(1), 67-70.

[18] Claesson, M. J., Jeffery, I. B., Conde, S., et al.: Gut microbiota composition correlates with diet and health in the elderly. Nature, 2012, 488(7410), 178-184

[19] Voigt, R. M., Forsyth, C. B., Green, S. J., et al.: Circadian disorganization alters intestinal microbiota, PLoS ONE, 2014, 9(5), e97500.

[20] Brody, T.: Nutritional Biochemistry. (2nd ed.) Academic Press, San Diego, California, 1999.
[21] Wong, J. M., de Souza, R., Kendall, C. W., et al.: Colonic health: fermentation and short chain fatty acids. J. Clin. Gastroenterol., 2006, 40(3), 235-243.

[22] Layden, B. T., Angueira, A. R., Brodsky, M., et al.: Short chain fatty acids and their receptors: new metabolic targets. Transl. Res., 2013, 161(3), 131-140.

[23] Puddu, A., Sanguineti, R., Montecucco, F., et al.: Evidence for the gut microbiota short-chain fatty acids as key pathophysiological molecules improving diabetes. Mediators Inflamm., 2014, 2014, 162021.

[24] Lin, H. V., Frassetto, A., Kowalik, E. J. Jr., et al.: Butyrate and propionate protect against diet-induced obesity and regulate gut hormones via free fatty acid receptor 3 -independent mechanisms. PLoS ONE, 2012, 7(4), e35240.

[25] $W u, H . J ., W u, E .:$ The role of gut microbiota in immune homeostasis and autoimmunity. Gut Microbes, 2012, 3(1), 4-14.

[26] Kim, C. H., Park, J., Kim, M.: Gut microbiota-derived shortchain fatty acids, $\mathrm{T}$ cells, and inflammation. Immune Netw., 2014, 14(6), 277-288.

[27] Carabotti, M., Scirocco, A., Maselli, M. A., et al.: The gut-brain axis: interactions between enteric microbiota, central and enteric nervous systems. Ann. Gastroenterol., 2015, 28(2), 203-209.

[28] Thakur, A. K., Shakya, A., Husain, G. M., et al.: Gut-microbiota and mental health: current and future perspectives. J. Pharmacol. Clin. Toxicol., 2014, 2(1), 1-15.

[29] Montiel-Castro, A. J., González-Cervantes, R. M., Bravo-Ruiseco, $G$., et al.: The microbiota-gut-brain axis: neurobehavioral correlates, health and sociality. Front. Integr. Neurosci., 2013, 7, 70.

[30] Guarner, F., Malagelada, J. R.: Role of bacteria in experimental colitis. Best Pract. Res. Clin. Gastroenterol., 2003, 17(5), 793804.

[31] Brandsma, E., Houben T., Fu, J., et al.: The immunity-diet-microbiota axis in the development of metabolic syndrome. Curr. Opin. Lipidol., 2015, 26(2), 73-81.

[32] Shi, I., Kokoeva, M. V., Inouye, K., et al.: TLR4 links innate immunity and fatty acid-induced insulin resistance. J. Clin. Invest., 2006, 116(11), 3015-3025.

[33] Cani, P. D., Bibiloni, R., Knauf, C., et al.: Changes in gut microbiota control metabolic endotoxemia-induced inflammation in high-fat diet-induced obesity and diabetes in mice. Diabetes, 2008, 57(6), 1470-1481.

[34] Cani, P. D., Amar, J., Iglesias, M. A., et al.: Metabolic endotoxemia initiates obesity and insulin resistance. Diabetes, 2007, 56(7), 1761-1772.

[35] Kitchens, R. L.: Role of CD14 in cellular recognition of bacterial lipopolysaccharides. Chem. Immunol., 2000, 74, 61-82.

[36] Batra, A., Pietsch, J., Fedke, I., et al.: Leptin-dependent Toll likereceptor expression and responsiveness in preadipocytes and adipocytes. Am. J. Pathol., 2007, 170(6), 1931-1941.

[37] Cani, P. D., Neyrinck, A. M., Fava, F., et al.: Selective increases of bifidobacteria in gut microflora improve high-fat-diet-induced diabetes in mice through a mechanism associated with endotoxaemia. Diabetologia, 2007, 50(11), 2374-2383.

[38] Siebler, J., Galle, P. R., Weber, M. M.: The gut-liver-axis endotoxemia, inflammation, insulin resistance and NASH. J. Hepatol., 2008, 48(6), 1032-1034.

[39] Caricilli, A. M., Saad, M. J.: The role of gut microbiota on insulin resistance. Nutrients, 2013, 5(3), 829-851.

[40] Musso G., Gambino, R., Cassader, M.: Obesity, diabetes, and gut microbiota: the hygiene hypothesis expanded? Diabetes Care, 2010, 33(10), 2277-2284.

[41] Hartstra, A. V., Bouter, K. E., Bäckhed, F., et al.: Insights into the role of the microbiome in obesity and type 2 diabetes. Diabetes Care, 2015, 38(1), 159-165.

[42] Parekh, P. J., Arusi, E., Vinik, A. I., et al.: The role and influence of gut microbiota in pathogenesis and management of obesity and metabolic syndrome. Front. Endocrinol. (Lausanne), 2014, 5,47 . 
[43] Tsukumo, D. M., Carvalho-Filho, M. A., Carvalheira, J. B., et al.: Loss-of-function mutation in Toll-like receptor 4 prevents dietinduced obesity and insulin resistance. Diabetes, 2007, 56(8), 1986-1998.

[44] Hildebrandt, M. A., Hoffman, C., Sherrill-Mix, S. A., et al.: High-fat diet determines the composition of the murine gut microbiome independently of obesity. Gastroenterology, 2009, 137(5), 1716-1724.e2.

[45] Spencer, M. D., Hamp, T. J., Reid, R. W., et al.: Association between composition of the human gastrointestinal microbiome and development of fatty liver with choline deficiency. Gastroenterology, 2011, 140(3), 976-986.

[46] Festi, D., Schiumerini, R., Eusebi, L. H., et al.: Gut microbiota and metabolic syndrome. World J. Gastroenterol., 2014, 20(43), 16079-16094.

[47] Tai, N., Wong, F. S., Wen, L.: The role of gut microbiota in the development of type 1 , type 2 diabetes mellitus and obesity. Rev. Endocr. Metab. Disord., 2015, 16(1), 55-65.

[48] Flight, M. H.: Neurodevelopmental disorders: the gut-microbiome-brain connection. Nat. Rev. Neurosci., 2014, 15(2), 65.

[49] Toh, M. C., Allen-Vercoe, E.: The human gut microbiota with reference to autism spectrum disorder: considering the whole as more than a sum of its parts. Microb. Ecol. Health Dis., 2015, 26, 26309.

[50] Chassaing, B., Etienne-Mesmin, L., Gewirtz, A. T.: Microbiotaliver axis in hepatic disease. Hepatology, 2014, 59(1), 328-339.
[51] Hakansson, A., Molin, G.: Gut microbiota and inflammation. Nutrients, 2011, 3(6), 637-682.

[52] Eiseman, B., Silen, W., Bascom, G. S., et al.: Fecal enema as an adjunct in the treatment of pseudomembranous enterocolitis. Surgery, 1958, 44(5), 854-859.

[53] Borody, T. J., Khoruts, A.: Fecal microbiota transplantation and emerging applications. Nat. Rev. Gastroenterol. Hepatol. 2011, $9(2), 88-96$.

[54] Vincze, Á.: Fecal transplantation. [Székletátültetés.] Magyar Belorvosi Archívum, 2015, 68(3), 153-155. [Hungarian]

[55] Chen, Z., Guo, L., Zhang, Y., et al.: Incorporation of therapeutically modified bacteria into gut microbiota inhibits obesity. J. Clin. Invest., 2014, 124(8), 3391-3406.

[56] Li, J. V., Ashrafian, H., Bueter, M., et al.: Metabolic surgery profoundly influences gut microbial-host metabolic-crosstalk. Gut, $2011,60(9), 1214-1223$.

[57] Cho, $\Upsilon$. M.: A gut feeling to cure diabetes: potential mechanisms of diabetes remission after bariatric surgery. Diabetes Metab. J., $2014,38(6), 406-415$.

\section{FELHÍVÁS folyóirat-referátumok beküldésére}

A Semmelweis Egyetem Továbbképző Központjának döntése értelmében 2016. január 1-jétöl folyamatosan orvos-továbbképzési pontokat kaphatnak a nemzetközi, impaktfaktoros folyóiratokban megjelent közlemények rövid összefoglalásának, referátumának beküldői.

Az Orvosi Hetilap hasábjain megjelenő és közlésre elfogadott referátum után 1 pont, félévente maximum 12 továbbképzési pont gyüjthető, amelyet félévente összesitve továbbítunk a továbbképzési központok felé.

Távoktatással szerzett pontokból évente legfeljebb 20 pont számítható be.

Aki továbbképzési pontot kiván gyüjteni, a referátum beküldésekor adja meg pecsétszámát.

Várjuk lelkes, továbbképzési pontokat gyüjteni kivánó referálóink jelentkezését!

\section{A referátum fejlécében az alábbi adatokat kérjük megadni:}

A cikk címe magyarul, zárójelben az angol cím

A szerző(k) neve (vezetéknév, a keresztnevet jelölö betü(k) - 3 szerzőig, háromnál több szerző esetén et al.), a levelező szerző neve, munkahelye és e-mail címe)

A folyóirat neve - a szokásos nemzetközi rövidítés szerint (PubMed), évszám, kötetszám, füzetszám, a cikk kezdő és utolsó oldalszáma

A referátumot elektronikus úton (Editorial Manager vagy e-mail: edit.budai@akademiai.hu) kérjük elküldeni. 